\author{
INTERNATIONAL JOURNAL OF \\ EDUCATION, PSYCHOLOGY \\ AND COUNSELLING \\ (IJEPC) \\ www.ijepc.com
}

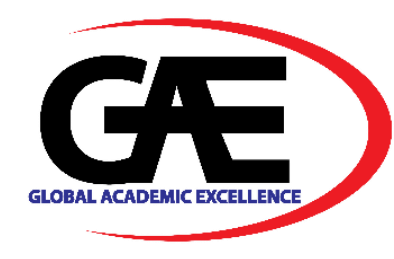

\title{
AN INTERVIEW ABOUT USING ONLINE GAMES IN VOCABULARY ACQUISITION AMONG THE SECOND YEAR STUDENTS OF UNIVERSITY COLLEGE SABAH FOUNDATION
}

\author{
Mohammad Aqmal Hafidz Musa ${ }^{1 *}$, Wan Hurani Osman ${ }^{2}$, Anna Lynn Abu Bakar ${ }^{3}$, Bernadette Tobi $^{4}$
}

1 Pusat Penataran Ilmu dan Bahasa, Universiti Malaysia Sabah, Malaysia

Email: aqmalhafidz@ums.edu.my

2 Pusat Penataran Ilmu dan Bahasa, Universiti Malaysia Sabah, Malaysia

Email:wanosman@ums.edu.my

3 Pusat Penataran Ilmu dan Bahasa, Universiti Malaysia Sabah, Malaysia

Email: annalynn@ums.edu.my

$4 \quad$ Pusat Penataran Ilmu dan Bahasa, Universiti Malaysia Sabah, Malaysia

Email: bernadette@ums.edu.my

* Corresponding Author

\section{Article Info:}

Article history:

Received date: 15.05 .2021

Revised date: 24.06 .2021

Accepted date: 20.07 .2021

Published date: 31.07.2021

\section{To cite this document:}

Musa, M. A. H., Osman, W. H., Abu Bakar, A. L., \& Tobi, B. (2021). A Case Study on Mandarin Text-ToSpeech. International Journal of Education, Psychology and Counseling, 6 (41), 199-215.

DOI: $10.35631 /$ IJEPC.641015

\begin{abstract}
:
The purpose of this study is to investigate the vocabulary acquisition among English as a second language (ESL) Learners. The study is based on grounded theory research designs. Grounded theory allows the study to generate a farreaching comprehensible theory founded on behaviourism, cognitivism, and constructivism on the central phenomenon (using online games in vocabulary learning); from the results and findings (Creswell, 2012). A systematic design is applied which highlights the use of data analysis procedures of open, axial, and selective coding, as well as the development of logic paradigm or visual picture(s) from the generated theory (Creswell, 2012). The interview protocol consists of three parts: personal information, advantages and disadvantages factors, as well as possible factors that support or inhibit vocabulary acquisition. Based on the findings, there are basically eight (8) descriptor codes, and thirty (30) in-vivo codes. All of these codes are emerged from the inductive coding method. The Emerging possible categories from the first sample: The possible categories that could be derived from the pattern of codes are: a. Personal preferences \& knowledge on computer or online games, b. Habitual playtime on playing computer or online games, c. Online games \&
\end{abstract}


Volume 6 Issue 41 (July 2021) PP. 199-215

DOI 10.35631/IJEPC.641015

Special Issue: Supporting the Continuation of Language Teaching and

Learning at Malaysian Higher Education Institution

This work is licensed under CC BY 4.0

()(1) learning English vocabulary, and d. Factors that could hinder learning English vocabulary.

Keywords:

Vocabulary, Online, Intra-Lexical, Extra-Lexical, Independent, Role-Playing Games (RPGs)

\section{Introduction}

The study aims to do a grounded theory research on Using Online Games in Vocabulary Learning among the Second Year Students in University College Sabah Foundation. The research objectives of this study are:

a. To describe the usage of online games in English as the second language (ESL) vocabulary learning among the second-year students in University College Sabah Foundation (UCSF).

b. To discover UCSF second year students' preferences of ways to learn ESL vocabulary in regards to online games

The approach of this study is mainly centred on qualitative study. It is hypothesised that online games could improve English as a Second Language (ESL) learners' vocabulary learning. Hence, this chapter presents the research methodology as a guide in conducting the study to describe the usage of online games in English as the second language (ESL) vocabulary learning among the second-year students in University College Sabah Foundation (UCSF).

\section{Figure 1: The Conceptual Framework of This Study}

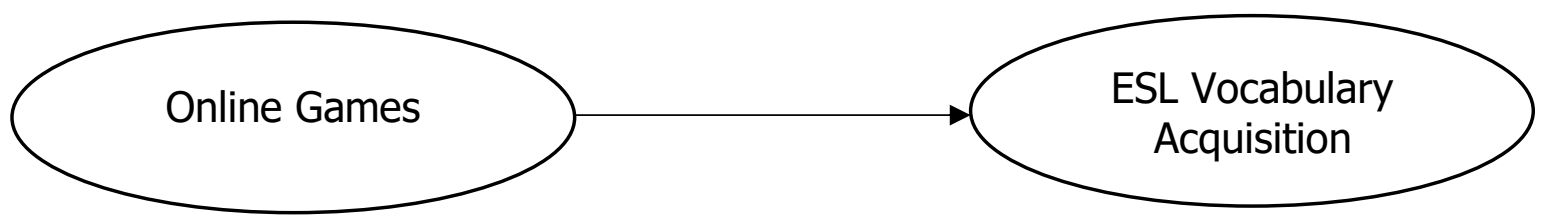

The conceptual framework of this theory could be first based on the foundation of vocabulary in the advancement of the four skills, which are reading, writing, listening and speaking (Nation, 2001; SULVA, 2015; Matsubara, 2018). There are the intra - lexical and extra lexical factors which could positively influence ESL learners' vocabulary learning as well. Moreover, the extra-lexical factors like personal interest and motivation are most likely to influence the ESL users' attitude to better acquire and learn English vocabulary.

\section{Intra-Lexical and Extra-Lexical Factors}

There are two factors that influences vocabulary acquisition and learning: the intra-lexical and extra-lexical factors (Vasileaidou, 2017). Intra-lexical factors focuses on the intrinsic properties of words' which could affect the process of learning vocabulary (Vasileaidou, 2017; Laufer, 1990, p. 134). The intrinsic factors include pronunciation, orthography, length, 


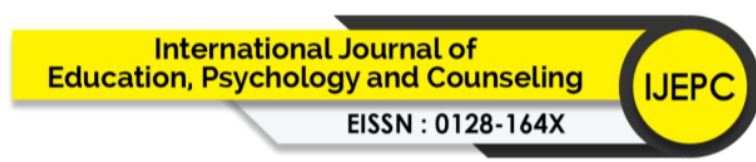

Volume 6 Issue 41 (July 2021) PP. 199-215

DOI 10.35631/IJEPC.641015

Special Issue: Supporting the Continuation of Language Teaching and Learning at Malaysian Higher Education Institution

morphology, synformy, level of abstractness, specificity, idiomaticity, and multiplicity of meaning (Vasileaidou, 2017; Laufer, 1990, p. 134). On the other hand, extra-lexical factors could speed up and slow down the process of learning vocabulary (Vasileaidou, 2017; Ellis, 1994). Extra-lexical factors consist of the learners' personal factors like their existing knowledge (language experience), motivation, attitudes, social factors, and learning environment (Vasileaidou, 2017, Boonkongsem, 2012). Hence, these intra-lexical and extralexical factors does positively influence the ESL users' vocabulary acquisition and learning. Moreover, the extra-lexical factors like personal interest and motivation are most likely to influence the ESL users' attitude to better acquire and learn English vocabulary. In addition, ESL students were found to have shown positive attitudes towards learning English via computer games (Nadzrah Abu Bakar, 2013).

\section{Vocabulary Learning in Malaysian Education}

The English as a second language (ESL) learners (students) in Malaysia are being exposed and taught English vocabulary mainly through books. There is a concern that a lot of Malaysian ESL (English as a Second Language) students are not proficient enough in the English language. Even though Malaysian ESL students are being instructed for six (primary levels) to twelve years (secondary levels) of school in the language.

Naginder (2013) in her study of the need for autonomous vocabulary learners in the Malaysian ESL classroom mentioned that the focus of English language in Malaysian context is failing to perform various functions outside of the classroom like in business, economics, finance and marketing. In the context of Malaysian university English Test (MUET), Naginder (2013) further states that ESL learners' performance in MUET from June 2000 to December 2002 had found that less than $1 \%$ candidates who sat for the exam achieved Band 6 (Very Good User) (Wan Norliza Wan Mustapha, 2002). The results were critical on November 2006 where 29.2\% of the students who sat for the exam achieved Bands 1 and 2 (Limited Users and below) (Naginder Kaur, 2013; Chapman, 2007). Besides, Haryati, Melor, \& Nor (2016) in their study on English vocabulary size and vocabulary learning strategies of UiTM pre-diploma students mentioned the decline in the standard of English among Malaysian ESL learners over the recent years could be from the issue of not properly applying the right language learning strategies.

\section{Problem Statement}

In order for language learners to learn the language they should first know its vocabulary. It is certain that vocabulary plays a role in the device of language learning (Kayaalti, 2018). For that reason, vocabulary learning strategies are essential in guiding students to become independent learners. In the process of achieving independent learning, students will develop their self-confidence in decision making, while reflecting on their ability to learn ESL vocabulary (Abu Bakar, 2013, p. 236). Online games are one of the main streams application used by people in regards to age and gender; especially among students (as the second language users). Online games like massively multiplayer online role-playing games (MMORPGs) along with real-time strategies provide students with the chance to practice ESL with other players (people) in-game (Yudintseva, 2015). Furthermore, Gee (2005), mentions Digital Game-Based Learning (DGBL) and computer games could be a self-study tool in the process of learning the language (as cited in. Abu Bakar, 2013, p. 236). 


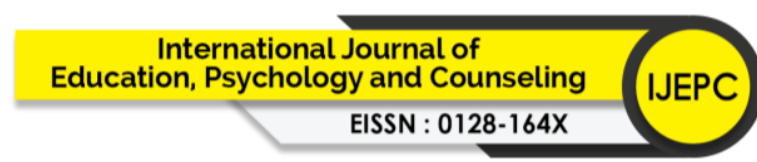

Volume 6 Issue 41 (July 2021) PP. 199-215

DOI 10.35631/IJEPC.641015

Special Issue: Supporting the Continuation of Language Teaching and Learning at Malaysian Higher Education Institution

Over the years, it is said that the student's mastery over ESL vocabulary is weakening over the time. One of the studies done in University Teknologi Mara (UiTM) found that majority of the university students were unable to understand the ESL classroom instruction, average numbers were not able to catch up certain spoken words, and some did not understand the meaning of uttered words (Khalijah binti Mohd Nor et al, 2019). Students also took longer time to write essay and were not able to comprehend the topic given during ESL instruction (Khalijah binti Mohd Nor et al, 2019).

Henceforth, the solution to this predicament could be by implementing online games as instructional strategy to enhance ESL learners' vocabulary acquisition. Improving students' vocabulary learning strategies could be the implication of online games. Several studies discovered that ESL learners found learning vocabulary to be easier while playing games (Yudintseva, 2015). Besides, Yuudintseva (2015) discusses several strategies that the students can use to learn vocabulary while playing games: Determination Strategies: contextual clues and Word Lists, Social Strategies: interactions with native speakers and peers, Memory Strategies: imagery and Metacognitive Strategies: media (p. 104 - 106). Hence, online games could develop students' capability to learn English as a second language (ESL) strategically.

\section{Literature Review}

The literature review is based on the three main-stream grounded theories which are behaviourism, cognitivism, and constructivism. The corpus of knowledge focuses on the aspect of using technology in vocabulary learning. Technology applied in this study is the usage of online games among English as a second language (ESL) learners. The reasons as to why online games was chosen as medium to learn ESL vocabulary is due to the factor of incidental learning, and the factor of interest in intrinsic motivation. For that reason, the effect of using online games in vocabulary learning could develop ESL learners' own learning styles; especially in term of field dependence and independence (DPI). In view of that, it will directly or indirectly affects ESL learners' sensory register control processes when playing online games to have actually learn or acquire vocabulary. Therefore, it eventually involves the cognitive process of ESL learners to constructively learn, understand and even apply the vocabulary.

\section{Using Technology in Vocabulary Learning}

Technology is becoming more and more sophisticated and has expanded the range of our experience. It has become tools for reading, science and math, art, multimedia, hypermedia and virtual environments - especially in entertainment. The development of virtual environment (like virtual online games) provides students (ESL learners) with vast learning experiences (Snowman, 2012). The cycle of achieving equilibration in that context to learn or acquire ESL vocabulary is much higher as it provides positive learning environment. Furthermore, online games can spark students' interest in learning ESL vocabulary incidentally and intentionally. And multimedia games can boost motivation and nurturing the process of ESL vocabulary learning (Ghanbaran, 2014). Therefore, online games provide comfortable learning environment for students to learn English vocabulary as the second language (L2).

\section{Online Games as a Medium to Learn Vocabulary}




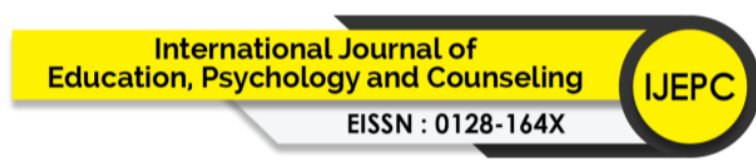

Volume 6 Issue 41 (July 2021) PP. 199-215

DOI 10.35631/IJEPC.641015

Special Issue: Supporting the Continuation of Language Teaching and Learning at Malaysian Higher Education Institution

Online games are one of the most popular application used, and there are several studies done to investigate the relationship between online games and vocabulary acquisition. A study conducted by Vasileaidou \& Makrina (2017) on using online games computer games in the ELT classroom; had found that computer games could improve students' vocabulary learning. The findings further stated that the control group scored below $25 \%$ while the experimental group scored around $56.8 \%$ and none scored below $25 \%$. Similar study was done by Nadzrah and Elaheh (2013) on sustaining vocabulary acquisition through computer games. The purpose of the study was to explore how computer games could be a tool to sustain vocabulary among the ESL adult learners. Three adult ESL learners (below intermediate level) between the age of 22 and 30 were selected. The findings had shown that all three ESL adult learners have positive attitudes in learning the English vocabulary. An average of 116.66 words were learned by each individual. Moreover, all three participants' test scores had increased in marks within the range of $60 \%$ to $87 \%$ from the range of $33 \%$ to $54 \%$. Another study on game-enhanced second language vocabulary acquisition strategies: a systematic review was conducted by Yudintseva (2015). The findings stated the analysis of quantitative, qualitative and mixed methods exposed that games enhanced ESL learners' visual imagery, language repetitions, as well as exposure to slang and colloquial language.

\section{Incidental Vocabulary Acquisition}

The studies conducted by Brown (2008), Fard (2013) and Meier (2015) in examining the incidental vocabulary acquisition methods are found to be related to this study. Brown (2008) in his study identified three methods in incidental vocabulary acquisition, namely reading, reading while listening, and listening to stories. The study by Brown (2008, p. 136) also examined the rate at which English vocabulary was acquired from the three input modes. The study of applying the three input modes showed that vocabulary can be acquired incidentally. According to Brown (2008, p.136), the result of the study proves that the incidental learning of vocabulary could happened. The concept of the current study is likely related to the third input mode, listening to stories which is considerably similar in listening to songs. Henceforth, the study done by Brown (2008) could support the basis in acquiring vocabulary incidentally through technology like online games or other usage of technologies.

Fard (2013) recognizes the study of incidental vocabulary acquisition by way of reading for pleasure. His study aims to examine the incidental acquisition of vocabulary from reading for pleasure against the traditional method. The study by Fard $(2013$, p. 72$)$ revealed that more vocabulary is acquired through incidental way than intentional way. The results support the element of pleasure in incidental vocabulary acquisition which could be related to the current topic in terms of using technology in vocabulary acquisition and learning among the ESL learners. This is because, role playing games provide players with the immersion of the stories that involves listening and reading.

Meier (2015) conducts a study on ESL incidental vocabulary acquisition through extensive listening to podcasts. The concept of his study is almost similar to that of Brown (2008) third input method, listening to stories. Podcasts is basically a digital audio file from the internet and electronic devices like smart phones, $\mathrm{mp} 3$ or $\mathrm{mp} 4$. Besides, podcasts are vastly used especially when listening to songs. Hence, it is likely for ESL learners to use podcasts in their everyday 


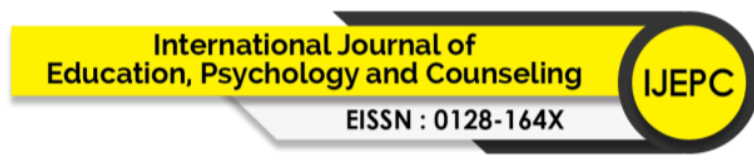

Volume 6 Issue 41 (July 2021) PP. 199-215

DOI 10.35631/IJEPC.641015

Special Issue: Supporting the Continuation of Language Teaching and Learning at Malaysian Higher Education Institution

life mainly for leisure and other purposes. In addition, the study by Meier (2015) had stressed on the implication of extensive listening skill for the ESL learners to acquire new vocabulary incidentally. Meier (2015, p. 73) found that the students participated in his study were love to listen podcasts although the vocabulary was sometimes challenging for them. Meier (2015, p. 79) also found that using podcasts (technology) can support the objective of vocabulary acquisition.

\section{The Effect of Interest on Intrinsic Motivation}

Intrinsic motivation is referring to behaviour that is driven by internal rewards. In addition, interest can be described as a psychological state that involves focused attention, increased cognitive functioning, persistence and emotional involvement (Snowman, 2012, p. 377). The correlation between interest and intrinsic motivation could link to ESL learners' technology (online games) preferences to satisfy their needs. Likewise, Snowman (2012, p. 369) stated that intrinsic motivation occurs when learner does something to experience inherently satisfying results. Two previous studies conducted by Sadeghi (2013) and Moya (2014) were examined.

Sadeghi (2013) conducts a study on the impact of achievement motivation on vocabulary learning in intermediate EFL learners. The study aims to investigate the impact of motivation on EFL learners' vocabulary learning. The study administered an Oxford Placement Test (OPT) in analysing the participants' consistency in their language proficiency. Besides, Hermans' scale of achievement motivation is applied to measure the participants' level of motivation. The study consists of two groups of highly-motivated and less-motivated people. Sadeghi (2013) then compared the two groups based on their vocabulary test achievement. It was found that highly motivated learners outperformed the less motivated learners (Sadeghi, 2013 , p. 206). In other words, the higher the ESL learners' motivation in learning vocabulary, the higher their vocabulary knowledge. The finding found by Sadeghi (2013) could support the usage of technology in vocabulary acquisition and learning as explained in 1.2.

Moya (2014) in his study on enhancing motivation in vocabulary learning had set an objective to identify methodology differences between behaviourist and cognitive-based in increasing students' motivation. The study assumes that cognitive-based approach is more effective than behaviourist approach. The result revealed that cognitive-based method proved to be more useful for teaching vocabulary (Moya, 2014, p. 6). In relation to motivation, the study also found that the students who had a high motivation obtained better results and they acquired the vocabulary with ease by using the cognitive methodology. The students feel more motivated and learn easily by using a cognitive method in which they can relate the vocabulary to their previous experiences and knowledge (Moya, 2014, p. 6). Henceforward, cognitive-based approach implementation could be related to the current topic in the aspect of thinking, remembering and learning ESL. The reason is that cognitive-based approach with motivation is seen share similarities with the effects of using online games (cognitive-based enhancing motivation) for ESL learners to acquire vocabulary. The ESL learners can easily relate to their previous vocabulary knowledge especially when they are exposed to the use of technology in everyday life.

\section{Learning Styles}




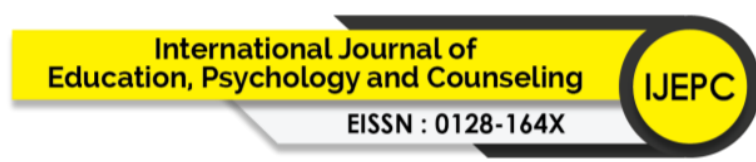

Volume 6 Issue 41 (July 2021) PP. 199-215

DOI 10.35631/IJEPC.641015

Special Issue: Supporting the Continuation of Language Teaching and

Learning at Malaysian Higher Education Institution

Learning styles is defined as distinguishing and organizing information based on one's consistent preferences over time and subject matter (Snowman, 2012; Sternberg \& Grigorenko, 2001; Zhang \& Strenberg, 2006, 2009). One of the famous learning style called field dependence - field independence could influence the vocabulary acquisition and learning process among the ESL learners (Snowman, 2012; Witkin, Moore, Goodenough, \& Cox, 1997).

\section{The Influence of Field Dependence and Independence}

Hamidreza (2014) examines the causal correlation between field-dependence and independence cognitive style and vocabulary learning strategies. He further explained that cognitive style can be referred as psychological aspect in acquiring and processing information. It includes thinking, perceiving, remembering or problem solving. The results of the study showed a causal correlation between field dependence and independence cognitive styles and vocabulary learning strategies (Hamidreza, 2014, p. 100). The context of cognitive styles could actually be related to the topic as online games can be a learning strategy to acquire vocabulary.

Nozari (2015) studies the relationship between field dependence and independence cognitive style and understanding English reading text to academic success. This study uses a similar concept of study done previously by Hamidreza (2014) in the application of cognitive style theory. The objective of this study is to identify the relationship between field dependence and independence (FDI) cognitive-style towards reading text comprehension. The study shows that the field independence students performed better in engaging environment when learning language (Nozari, 2015, p. 44). Thus it proves that FDI cognitive styles play an important role in second language comprehension skills (Nozari, 2015, p. 44). For that reason, it applies in the setting of online games as it does implement a story setting which player(s) have to read, or listen to the dialogue or text in-game.

\section{Sensory Register Control Processes in Memorization}

Snowman (2012) mentioned that human receptors are initially recorded in the sensory register (p. 253). The concept is identical in the visualization and even listening and speaking processes. Snowman (2012) briefly illustrated that the input received by sensory register (SR) is to be stored in short-term memory (STM) or long term memory (LTM) in responses to output or acquired vocabulary (p. 252). In the case of the current study, it uses online games as the environmental stimuli (input) to sensory register (SR). There are two studies to elaborate SR in vocabulary memorization found to be related to the current study, that were the study conducted by Liu (2011) and Yang (2012).

Liu (2011) conducts a study on vocabulary recognition and memorization: a comparison of two methods. The study examines two different methods to identify which offers long-term retention of meaning and spelling. The two methods used in the study are rote learning and learning by sentence writing. This can be related to the reading skill in the current study perspective as reading could happen in the game. Nonetheless, the importance of this study cannot be neglected as it contributes to the result of vocabulary recognition and memorization. The result demonstrates that pupils who learn words using lists only remember words in the short-term retention, while the sentence writing method results in greater long-term retention 


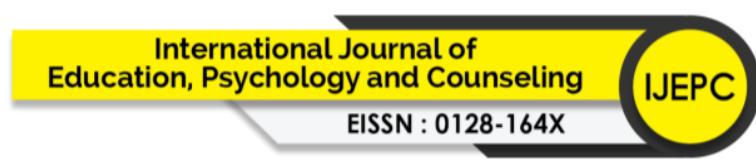

Volume 6 Issue 41 (July 2021) PP. 199-215

DOI 10.35631/IJEPC.641015

Special Issue: Supporting the Continuation of Language Teaching and Learning at Malaysian Higher Education Institution

(Liu, 2011, p. 31). Sentence writing could pose similar attributes in the online game's script stories. This is because, the words are not listed but are properly structured to convey meaning. Liu (2011) mentions that learning by written sentences involves deeper processing than learning by words list (p. 32). For that reason, the element of stories existed in online games especially in role playing games (RPG) could greatly enhance ESL learners vocabulary learning.

Yang (2012) studies the vocabulary memorizing strategies. Yang (2012) applies four strategies that are rote repetition, structural associations, semantic strategies, and mnemonic keyword techniques. The result of the study showed that structural associations and semantic strategies are the two approaches favoured by the students followed by repetition. The findings indicate that students prefer to engage in vocabulary learning strategies that would be most appealing, and entail less manipulation of the language (Yang, 2012, p. 208). These findings could support the current study on the usage of online games in incidental vocabulary acquisition. This is because online games are appealing and are likely to less manipulate the ESL learners to learn vocabulary in formal context.

\section{Cognitive Process in Learning Vocabulary}

Cognitivism has greatly influence technology through gamification in the development of second language (L2) teaching and learning. A study on an investigation of the cognitive processes underlying the keyword method (KWM) of foreign vocabulary learning was conducted by Shapiro (2005). One of the reasons why KWM is effective is due to the factor of visual memory. "It is well documented within the cognitive literature that visual stimuli create very strong memory" (Shapiro, A. M., \& Waters, D. L., 2005). The findings further stated that the imagery value of the word learned effectively enhanced ESL learners to further recall vocabulary. In relation to technology, (online games) application does provide a lot of visual imagery towards the players (ESL learners) which further construct their knowledge more on acquiring L2 vocabulary.

Gaogao \& Xueping (2013) had done a study on classroom monitoring vocabulary acquisition based on cognitive semantics. The study indicates the use of individual learning techniques (as mentioned in 1.3) from the perspective of cognitive psychology. Further findings states that vocabulary acquisition could be developed through ESL learners' own realization in selfmonitoring, mastering their own learning strategies, as well as developing positive learning attitudes and habit through classroom monitoring. In regards to technology and online games application, the virtual environment itself could be the source for ESL students to adapt while accepting and mastering their own learning strategies, along with self-evaluation. The application of online games for example could give insights towards L2 users to systematically (strategically) acquire the language by instruction. Social strategies for instance could act as a medium of interaction between L2 users and the native speakers or their peers (Yuudintseva, 2015)

\section{Research Design}




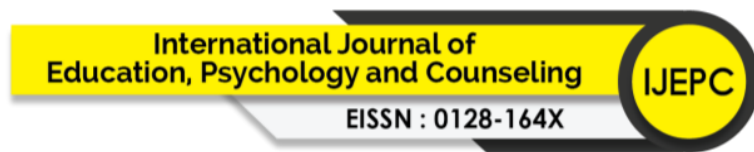

Volume 6 Issue 41 (July 2021) PP. 199-215

DOI 10.35631/IJEPC.641015

Special Issue: Supporting the Continuation of Language Teaching and Learning at Malaysian Higher Education Institution

The study is based on grounded theory research designs. Grounded theory allows the study to generate a far-reaching comprehensible theory founded on behaviourism, cognitivism, and constructivism on the central phenomenon (using online games in vocabulary learning); from the results and findings (Creswell, 2012). Furthermore, grounded theory design used a systematic, qualitative procedure to create theory(ies) that describes conceptual level, processes, actions and interactions of a substantive topic (Creswell, 2012).

A systematic design is applied which highlights the use of data analysis procedures of open, axial, and selective coding, as well as the development of logic paradigm or visual picture(s) from the generated theory (Creswell, 2012). Segmentation of the study category on interviews, observations, and documentations (memos or notes) - open coding (Creswell, 2012).

\section{Findings}

The sample of transcript can be seen in the figure 2 below:

\section{Figure 2: Sample of Interview Transcript}

\begin{tabular}{|c|c|}
\hline Joseva: & $\begin{array}{l}\text { Uhm (p) I think yes, }{ }^{12} \text { definitely going to benefit the } \\
\text { ah student em (p) in term of learning English } \\
{ }^{13} \text { because first of all the game is in English and you } \\
\text { can change the language but most people prefer to } \\
\text { play it in English and ahm (p) }{ }^{14} \text { I think it's even } \\
\text { better if it's like uh an online game like I mentioned } \\
\text { earlier because }{ }^{15} \text { we get to play with someone else } \\
\text { and ehm (p) you like this language barrier and ah } \\
{ }^{16} \text { fortunately there's ah (p) English language which } \\
\text { is the international language and that's the only } \\
\text { language that we used to communicate with each } \\
\text { other and uh I mean (pausing) (thinking tone) yeah } \\
\text { 17you'd improve someone's English over time and } \\
\text { it's entertaining at the same time so (p) it's kinda } \\
\text { like ah (p) (thinking tone) }{ }^{18} \text { it's better than studying } \\
\text { in my opinion because you get to enjoy it at the } \\
\text { same time you know. (exciting remark tone) }\end{array}$ \\
\hline Interviewer: & Alright, Aizat? \\
\hline Aizat: & $\begin{array}{l}\text { From }(p) \text { um point of view ah }(p) \text { (thinking tone) } \\
{ }^{19} \text { people will always learn English mostly from ah } \\
\text { (p) game. I also learn English from game, }{ }^{20} \text { from } \\
\text { there I learn more words. You (p) uh ( } p \text { ) uh }(p)^{21} \text { I } \\
\text { mean fix my vocabulary [inaudible] like that I think } \\
\text { (thinking tone) }\end{array}$ \\
\hline Interviewer: & Okay (p) Mazmil? \\
\hline
\end{tabular}

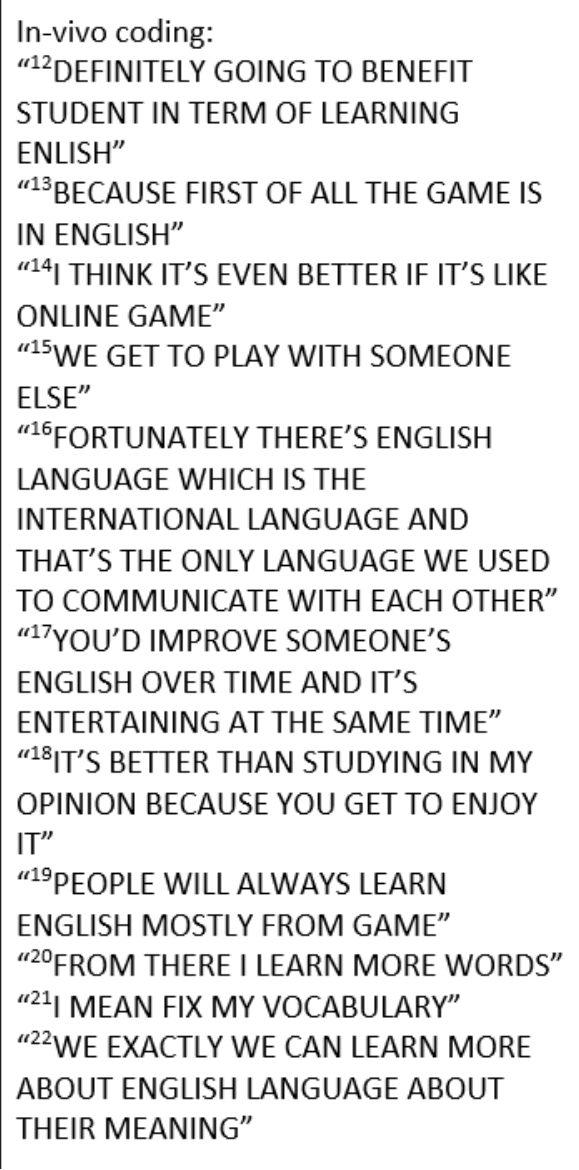

Furthermore, based on the findings of the interview transcript: The "Codes to Patterns" found in the interview transcript are listed down below: 
Volume 6 Issue 41 (July 2021) PP. 199-215 DOI 10.35631/IJEPC.641015 Special Issue: Supporting the Continuation of Language Teaching and Learning at Malaysian Higher Education Institution

1. “THREE STUDENTS FROM DIPLOMA IN BUSINESS MANAGEMENT WHO STUDIES BUSINESS ENGLISH" [Descriptive Code]

2. “FAMILIARITY WITH COMPUTER OR ONLINE GAMES" [Descriptive Code]

3. "LIST OF FAVOURITE COMPUTER, CONSOLE OR ONLINE GAMES” [Descriptive Code]

4. “'REASONS AS TO WHY THEY LOVE PLAYING THE COMPUTER OR ONLINE GAMES" [Descriptive code]

5. “HABITUAL PLAY TIME ON COMPUTER OR ONLINE GAMES” [Descriptive Code]

6. “6WHENEVER I HAVE TIME I WOULD PLAY” [In-vivo Coding]

7. "77LMOST EVERY DAY" [In-vivo Coding]

8. “8MAYBE THREE TIMES PER DAY” [In-vivo Coding]

9. "을

10. “10THREE TIMES LIKE ONCE A WEEK” [In-vivo Coding]

11. " "COMPUTER/ONLINE GAMES AND ENGLISH VOCABULARY LEARNING" [Descriptive Code]

12. “'DEFINITELY GOING TO BENEFIT STUDENT IN TERM OF LEARNING ENLISH" [In-vivo Coding]

13. “13BECAUSE FIRST OF ALL THE GAME IS IN ENGLISH” [In-vivo Coding]

14. “14 I THINK IT'S EVEN BETTER IF IT'S LIKE ONLINE GAME” [In-vivo Coding]

15. “15WE GET TO PLAY WITH SOMEONE ELSE” [In-vivo Coding]

16. " ${ }^{16}$ FORTUNATELY THERE'S ENGLISH LANGUAGE WHICH IS THE INTERNATIONAL LANGUAGE AND THAT'S THE ONLY LANGUAGE WE USED TO COMMUNICATE WITH EACH OTHER" [In-vivo Coding]

17. “17YOU'D IMPROVE SOMEONE'S ENGLISH OVER TIME AND IT'S ENTERTAINING AT THE SAME TIME" [In-vivo Coding]

18. “' ${ }^{18}$ IT'S BETTER THAN STUDYING IN MY OPINION BECAUSE YOU GET TO ENJOY IT" [In-vivo Coding]

19. “"19EOPLE WILL ALWAYS LEARN ENGLISH MOSTLY FROM GAME” [In-vivo Coding]

20. “20FROM THERE I LEARN MORE WORDS” [In-vivo Coding]

21. "21 I MEAN FIX MY VOCABULARY” [In-vivo Coding]

22. “22WE EXACTLY WE CAN LEARN MORE ABOUT ENGLISH LANGUAGE ABOUT THEIR MEANING" [In-vivo Coding]

23. “23FACTORS THAT COULD INHIBIT LEARNING ENGLISH VOCABULARY THROUGH ONLINE FAMES" [Descriptive Code]

24. "24TALKING TO SOMEONE WHO IS ALSO NOT REALLY GOOD IN ENGLISH” [In-vivo Coding]

25. “25ENGLISH IN VIDEO GAMES IS LIKE THE PEOPLE TO WHOM YOU TALK TO INFLUENCE YOU THE MOST" [In-vivo Coding] 
Volume 6 Issue 41 (July 2021) PP. 199-215 DOI 10.35631/IJEPC.641015 Special Issue: Supporting the Continuation of Language Teaching and Learning at Malaysian Higher Education Institution

26. “26SO IF YOU HANG OUT WITH SOMEONE WHO IS ALSO DON'T KNOW HOW TO PROPERLY SPEAK ENGLISH YOU'RE GONNA BE IN THE SAME SITUATION AS HIM" [In-vivo Coding]

27. “27YOU'RE NOT YOU'RE NOT REALLY GONNA IMPROVE MUCH” [In-vivo Coding]

28. “28I THINK THERE ARE NO NEGATIVE EFFECTS ON LEARNING ENGLISH GAMES BECAUSE OF WE LEARN MORE THINGS” [In-vivo Coding]

29. “29IF YOU PLAY SCI-FI GAME, YOU WILL LEARN ABOUT ASTRONOMY, ASTROLOGY, SCIENCE AND FROM THERE YOU WILL TEND TO SEARCH THE WORDS IN GOOGLE'S ONLINE" [In-vivo Coding]

30. “"30GAMES INFLUENCES IN LEARNING ENGLISH AS THE SECOND LANGUAGE" [Descriptive Code]

31. “31 COMMUNICATION IS KEY IN ORDER TO SUCCEED” [In-vivo Coding]

32. "31 SO IN A BETTER COMMUNICATION IT MEANS THE MORE LIKELY THAT YOUR TEAM GONNA WIN" [In-vivo Coding]

33. “33YYEAH I THINK THAT DEFINITELY MOTIVATES SOMEONE TO ACTUALLY LEARN ENGLISH" [In-vivo Coding]

34. " "34THEY CAN COMMUNICATE WIH THEIR TEAM-MATES” [In-vivo Coding] 35. "35IF YOU PLAY ONLINE GAMES YOU WILL SPEAK WITH OTHER PEOPLE FROM OTHER COUNTRIES AND THAT THE TIME YOU USE ENGLISH" [In-vivo Coding]

36. "36YOU WILL TEND TO LEARN ENGLISH TO COMMUNICATE WITH THEM” [In-vivo Coding]

37. “37FOR ME IF YOU'RE PLAYING ONLINE GAMES WE WILL MAKE NEW FRIENDS SO WE CAN HEARD NEW WORDS FROM THEM" [In-vivo Coding]

38. " ${ }^{38}$ WE CAN SHARE OR WE CAN ASK HIM ABOUT THE MEANING OF THE WORDS IF WE DON'T KNOW' [In-vivo Coding]

Patterning the 38 Codes by code types:

There are basically eight (8) descriptor codes, and thirty (30) in-vivo codes. All of these codes are emerged from the inductive coding method.

Emerging possible categories from the interview transcript:

The possible categories that could be derived from the pattern of codes are:

a. Personal preferences \& knowledge on computer or online games.

b. Habitual playtime on playing computer or online games.

c. Online games \& learning English vocabulary.

d. Factors that could hinder learning English vocabulary.

\section{Discussion}




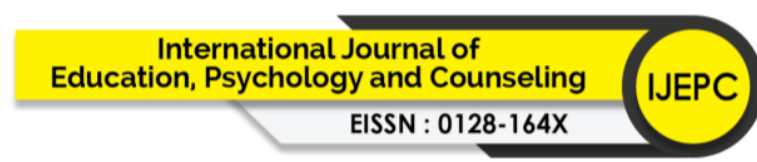

Volume 6 Issue 41 (July 2021) PP. 199-215

DOI 10.35631/IJEPC.641015

Special Issue: Supporting the Continuation of Language Teaching and Learning at Malaysian Higher Education Institution

From the emerging possible categories, the findings have found a how the students could use online games to learn English language vocabularies. The findings also discovered the students' personal preferences about how they could learn ESL vocabulary through online games.

Nevertheless, one of the challenges lies in the increase in variations of online games. The issue in different variations of online games could also affect students' attitudes towards learning to be positively and negatively affected. Yip and Kwan (2006) state that the learning of English vocabulary via online games could affect the ESL learners towards their attitudes in language learning (as cited in in. Ghanbaran, 2014, p. 492). The complications in variations are an issue in which the ESL instructors do not have full control over it, especially in the selection of online games.

The content of online games is first based on entertainment purposes but not fully cater to the process of learning (in an educational context). Because of that, there are issues with the applicable types for suitable online games to be used in the process of learning ESL vocabulary. Besides, the matter with using online games is its possibility of having non-contextualized practice in English as the second language (ESL) (Turgut, 2009).

Nonetheless, it is a challenge for the ESL instructors to contextualize the non-contextualized content of using online games in learning English vocabulary. One of the challenges is for teachers to provide -an environment where students can actively learn while playing online games. Positive contextual teaching and learning (CTL) require teachers and students to do some activities in the classroom, ensuring the learning process is centered on students (Kalchik, 2010). One possible way for language instructors to achieve successful CTL is to have a twoway interaction with students in the virtual (online) like a classroom in games. CTL needs students' - teacher(s) active participation, aid students in different types of instructions, and developing creative teaching and learning strategies (Kalchik, 2010). Moreover, virtual contextualized online classrooms in games could be difficult to achieve with the available technologies and resources in the process of vocabulary learning.

Thus, the focus of using online games in vocabulary learning in this study is hoping to find whether it could improve the performances of students (the second language users) to learn vocabulary. Furthermore, overcoming difficulties in contextualizing online games (in education) could open ways for language teachers to effectively teach ESL vocabulary. Besides, the variations of online games could give positive impacts on students rather than to negatively influence their attitudes towards learning ESL vocabulary.

Using games to learn ESL vocabulary or the language itself could become the foundation for a more interactive, systematic and futuristic formal or informal contextualised classroom in the future. Although there are pro and cons in regards to the application of using technology; it will still continue to evolve to cater the needs for teaching and learning. Some researchers mentioned that the uses of computer assisted instruction (CAI) and multimedia education have significantly changed the children's learning and cognitive processes (Aghlara \& Tamjin, 2011). Furthermore, digital games were found to help facilitate vocabulary learning and 


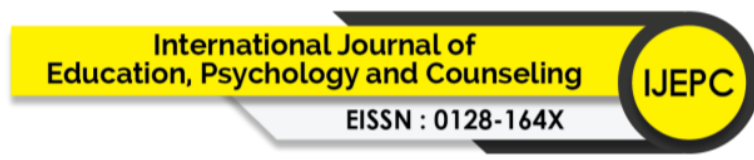

Volume 6 Issue 41 (July 2021) PP. 199-215

DOI 10.35631/IJEPC.641015

Special Issue: Supporting the Continuation of Language Teaching and

Learning at Malaysian Higher Education Institution

memorization through interaction - motivation which develops meaningful learning environment (Shahriarpur \& Kafi, 2014).

Therefore, the application of online games could help ESL learners to become independent learners. This is because, successful independent learning (IL) could facilitate ESL learners' motivation, cognition, affection, volition and emotion towards learning positively (Žydžiūnaitè, Teresevičienè, \& Gedvilienè, 2014). Besides, the study could help expose ESL learners towards ESL vocabulary in the context of reading, listening and interactions through the concept of online gaming. Moreover, the interaction with native speakers and other ESL or EFL speakers in anonymous informal gaming environment could likely reduce the anxiety and increase the English language exposure (Yudintseva, 2015).

Likewise, there are a lot of research gaps in the study of using online games in vocabulary acquisition. It is with hope that researchers could reduce the research gaps that studies the application of using online games in classroom instruction to help in ESL classroom instruction, especially when the world is now shift its full focus to online teaching and learning due to COVID-19.

\section{Conclusion}

The application of technology (through online games) could greatly help ESL learners to acquire and learn the L2 vocabulary. It does affect the extra-lexical factors more which in turn affects the inner-lexical factors in the process of learning vocabulary. Then again, the issues in the context of Malaysian education in learning English is that the teaching of L2 vocabulary is not interactive enough to spark ESL learners' personal interest. The possibility of applying technology in the teaching and learning of L2 vocabulary could significantly boost the extralexical factors of that ESL learners. The extra-lexical factors like motivation could elicit a learning environment where vocabulary could be acquired incidentally or intentionally. This could make ESL learners to come up with their own learning strategies through the application of technology (in the application of online gaming). Therefore, all of these processes will eventually lead into the development of constructing new knowledge (learning or acquiring vocabulary) via online games.

\section{References}

Asmaa Alsaqqaf. (n.d.). TT60104: Quantitative research. Kota Kinabalu: Universiti Malaysia Sabah.

Aghlara, L., \& Tamjid, N., H. (2011). The effect of digital games on Iranian children's vocabulary retention in foreign language acquisition. 1877-0428. doi:10.1016/j.sbspro.2011.11.275

Ahmed, S. (2017). Intentional learning vs incidental learning. Retrieved from https://www.researchgate.net/publication/315987506_Intentional_Learning_Vs_Incid ental_Learning

Alberta Hands \& Voices. (2017). Incidental learning. Retrieved from http://albertahandsandvoices.com/wp-content/uploads/2017/11/

Incidental_Learning.pdf 


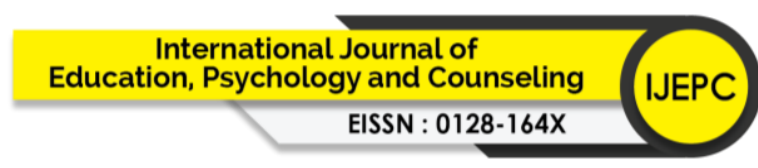

Volume 6 Issue 41 (July 2021) PP. 199-215

DOI 10.35631/IJEPC.641015

Special Issue: Supporting the Continuation of Language Teaching and

Learning at Malaysian Higher Education Institution

Alqahtani, M. (2015). The importance of vocabulary in language learning and how to be taught. Retrieved from https://www.iises.net/international-journal-of-teachingeducation/publication-detail-213?download=2

Ashraf, H., Motlagh, F., G., \& Salami, M. (2014). The impact of online games on learning English vocabulary by Iranian (low-intermediate) EFL learners. 1877-0428. doi: 10.1016/j.sbspro.2014.03.418

Azadeh Asgari., \& Ghazali Mustapha. (2011). The influence of informal language learning environment (parents and home environment) on the vocaulary learning strategies. doi:10.5539/ells.v1n1p7. Retrieved from www.ccsenet.org/ells

Azadeh Asgari., \& Ghazali Mustapha. (2011). The type of vocabulary learning strategies used by ESL stuents in University Putra Malaysia. doi:10.5539/elt.v4n2p84. Retrieved from www.ccsenet.org/elt.

Boonkongsaen, N. (2012). Factors affecting vocabulary learning. Naresuan University Journal, 20(2), 45-53.

Brian, D., \& Hastings, P. W. (2014). Addiction to the internet and online gaming. Retrieved from https://www.researchgate.net/publication/7802995

Brown, R., Waring, R., \& Donkaewbua, S. (2008). Incidental vocabulary acquisition from reading, reading while-listening, and listening to stories. Retrieved October 17, 2017, from http://www.nflrc.hawaii.edu/rfl/October2008/Brown/Brown.pdf

Camacho, P. (2018). Incidental or intentional learning? Two compatible processes. Retrieved from

https://www.researchgate.net/publication/331300347_Incidental_or_Intentional_Lear ning_Two_Compatible_Processe

Cresswell, J. H. (2012). Educational research: planning, conducting and evaluating quantitative and qualitative research. ( $4^{\text {th }}$ ed.). Lincoln: University of Nebraska.

Derakhshan, A., \& Khatir, E. (2015). The effects of using games on English vocabulary learning. Retrieved from www.jallr.ir

Dewa Putu Eskasasnanda. (2017). Causes and effects of online video game playing among junior-senior high school students in mMalang East Java. Retrieved from http://journal.unnes.ac.id/nju/index.php/komunitas

Dewi Nur Asyiah. (2017). The vcabulary teaching and vocabulary learning: perception, strategies, and influences on students' vocabulary mastery. Retrieved from http://ejournal.iain-tulungagung.ac.id/index.php/ls/article/view/701

Easterbrook, R., M. (2013). The process of vocabulary learning: vocabulary learning strategies and beliefs about language and language learning. Retrieved from http://www.canberra.edu.au/researchrepository/file/3384527a-1649-4e50-b61f32a9979276e6/1/full_text.pdf

Escribano, P., D. (2004). Exploring cognition processes in second language acquisition: the case of cognates and false-friends in EST. Retrieved from https://www.researchgate.net/publication/282610976_Exploring_cognition_processes _in_second_language_acquisition_the_case_of_cognates_and_false-friends_in_EST

Fraenkel, J. R., Wallen, N. E., \& Hyun, H. H. (2012). How to design and evaluate research in education. New York: McGraw-Hill. 
Volume 6 Issue 41 (July 2021) PP. 199-215

DOI 10.35631/IJEPC.641015

Special Issue: Supporting the Continuation of Language Teaching and Learning at Malaysian Higher Education Institution

Gee, J. P. (2005). Why video games are good for your soul: Pleasure and learning. Melbourne: Common Ground.

Gaogao, L., \& Xueping, Z. (2013). Classroom monitoring vocabulary acquisition based on cognitive semantics. Retrieved from https://www.atlantispress.com/proceedings/icetms-13/7168

Ghanbaran, S. \&. (2014). Multimedia games and vocabulary. 489-496. doi:10.4304/tpls.4.3.489-496

Gobet, F. (2015). Vocabulary acquisition. In James D. Wright (Ed.), International encyclopedia of the social \& behavioral sciences, $2^{\text {nd }}$ edition, Vol 25 (pp. 226-231). Oxford: Elsevier.

Goundar, P. (2015). Vocabulary learning strategies of English as foreign language (EFL) learners: a literature review. Retrieved from https://www.researchgate.net/publication/283031782

Haryati Ahmad, Melor Md Yunus, \& Nor Haniza Hasan. (2016). English vocabulary size and vocabulary learning strategies of UiTM pre-diploma students. Retrieved from https://pdfs.semanticscholar.org/05e5/9c2b2a065729ca32c9d748acca0bc70265e2.pdf.

Hamidreza, D. (2014). The causal correlation between field-dependence/independence cognitive styles and vocabulary learning. Retrieved October 17, 2017, from https://files.eric.ed.gov/fulltext/EJ1081668.pdf

Hulstijin, J. H. (2013). Incidental learning in second language acquisition. 2632-2640. doi: 10.1002/9781405198431.wbeal0530

Hyams, R., \& Sadique, D. (2014). The value of incidental learning in a multidisciplinary setting. $\quad$ Retrieved from https://www.researchgate.net/publication/291602587_The_Value_of_Incidental_Lear ning_in_a_Multidisciplinary_Setting

Kalchik, S. \&. (2010). The theory and application of contextualizd teaching and larning in relation to programs of study and career pathways. 1-6. Retrieved from https://www.researchgate.net/publication/234684911

Laufer, B. (1990). Why are some word more difficult to learn than others? Some intralexical factors that affect the learning of words. International Review of Applied Linguistics in Language Teaching, 28(4), 293-308. https://doi.org/10.1515/iral.1990.28.4.293

Matsubara, M., \& Yoshida, H. (2018). Fostering autonomous learners of vocabulary acquisition using content-based ICT methods. Retrieved from https://doi.org/10.18510/hssr.2018.617

McCarthy, M. J. (1990). Vocabulary. Oxford: Oxford University Press.

McMullen, M.G. 2009. Using language learning strategies to improve the writing skills of Saudi EFL students: will it really work? System 37, 418-433.

Meier, A. (2015). L2 incidental vocabulary acquisition through extensive listening to podcasts. Retrieved October 17, 2017, from https://journals.cdrs.columbia. edu/wpcontent/uploads/sites/12/2015/12/01-Meier_APPLE.pdf

Moya, I, G., \& Ferrando, I, N. (2014).Enhancing motivation in vocabulary learning: a cognitive approach. $\quad$ October 17, 2017, from https://www.textroad.com/pdf/JBASR/J.\%20Basic.\%20Appl.\%20Sci.\%20Res.\%203( 10)206-213,\%202013.pdf 


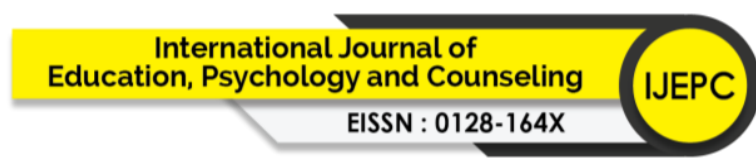

Volume 6 Issue 41 (July 2021) PP. 199-215

DOI 10.35631/IJEPC.641015

Special Issue: Supporting the Continuation of Language Teaching and

Learning at Malaysian Higher Education Institution

Nadzrah Abu bakar., \& Elaheh Nosratirad. (2013). Sustaining vocabulary acquisition through computer game: a case study. Retreived from http://dx.doi.org/10.5539/ass.v9n5p235

Naemi, M., \& Foo, T. C. V. (2015). Vocabulary acquisition through direct and indirect learning strategies. Retrieved from http://dx.doi.org/10.5539/elt.v8n10p142

Naginder Kaur. (2013). The need for autonomous vocabulary learners in the Malaysian ESL classroom. Retrieved from https://www.researchgate.net/publication/263392279

Nozari, Y. (2015). The relationship between field dependent-independent cognitive style and understanding of English. Retrieved October 17, 2017, from From https://www.ncbi.nlm.nih.gov/pmc/articles/PMC4384857/

Roslina Mohd Rasdi (2009). Vocabulary learning and teaching through student teachear negotiations in the malaysian ESL classroom. Retrieved from http://psasir.upm.edu.my/id/eprint/5684/

Rubijesmin Abdul Latif, Norshakirah Abdul Aziz, \& Mohd Taufik Abdul Jalil. (2017). Impact of online games among undergraduate students. Retrieved from http://www.uum.edu.my

Sadeghi, M. (2013). The impact of achievement motivation on vocabulary learning. Retrieved October 17, 2017, from http://repositori.uji.es/xmlui/bitstream/handle/10234/113460/TFM_2013_garciaI.pdf? sequence $=1$

Shahriarpour, N., \& Kafi, Z. (2014). On the effect of playing digital games on Iranian intermediate EFL learners' motiation towards English vocabularies. 1738 - 1743. doi: 10.1016/j.sbspro.2014.03.601

Shapiro, A. M., \& Waters, D. L. An investigation of the cognitive processes underlying the keyword method of foreign vocabulary learning. Retrieved from https://journals.sagepub.com/doi/10.1191/1362168805lr151oa

Snowman, J., McCown, R., \& Biehler, R. (2012). Psychology applied to teaching. (13 ${ }^{\text {th }}$ ed.). Wadsworth: Cengage Learning.

Spector, J. M. (2014). Technologies for intentional learning: beyond cognitive perspective. Retrieved from https://www.researchgate.net/publication/275493405

Sternberg, R. J., \& Grigorinko, E. L., \& Zhang, L. (2008). Styles of learning and thinking atter in instruction and assessment. Perspectives on Psychological Science, 3(6), 486-506.

Sydow, A. V. (2015). Vocabulary acquisition: possibilites within the task-based framework. Retrieved

from https://scholar.google.com.my/scholar?q=Vocabulary+acquisition:+possibilities+with in+the+task-based+framework\&hl=en\&as_sdt=0\&as_vis=1\&oi=scholart

Tang, E., chung, E., Li, C., \& Yeung, S. (2016). Online independent vocabulary learning experience of Hong Kong university students. Retrieved from https://iafor.org/journal/iafor-journal-of-education/volume-4-issue-1/article-1/

Tuan, L., T. (2011). An empirical research on self-learning vocabulary. 1688-1695. doi:10.4304/tpls.1.12.1688-1695.

Turgut, Y. \&. (2009). Young learners' language learning via computer games. 760-764. doi:10.1016/j.sbspro.2009.01.135

Vasileiadou, I. \&. (2017). Using online computer games in the ELT classroom: a case study. 10, 134-150. doi:10.5539/elt.v10n12p134 


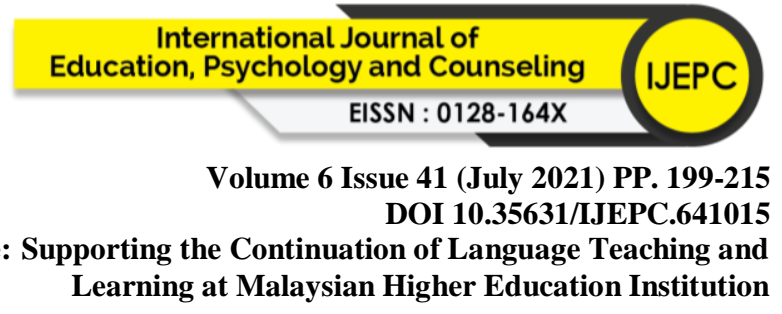

Wan Norliza Wan Mustapha (2002). MUET: The need to develop competent writers. In M. E. Vethamani (Series Ed.) \& S. A. Abdullah (Vol. Ed.), Preparing students for the Malaysian University English Test (MUET) (pp. 93-99). Petaling Jaya: Sasbadi Sdn. Bhd.

Witkin, H. A., Moore, C. A., Goodenough, D. R., \& Cox, P. W. (1977). Field-dependent and field-independent cognitive styles and their educational implications. Review of Educational Research, 47(1), 1-64.

Yudintseva, A. (2015). Game-Enhanced Second Language Vocabulary Acquisition Strategies: A Systmatic Review. 101-109. doi:10.4236/jss.2015.310015

Žydžiūnaitė, V., Teresevičienè, M., \& Gedvilienè, G. (2014). The structure of independent learning in higher education: students' attitude. Retrieved from https://www.researchgate.net/publication/283892173 